\title{
Ориентализмы-антропонимы в южнославянских устойчивых сравнениях
}

\begin{abstract}
И. В. КУЗНЕЦОВА
Кафедра педагогики и методики начального образования, Чувашский государственный педагогический университет им. И. Я. Яковлева, ул. К. Маркса, д. 38, RU-428000 Чебоксары

E-mail: irinak47@yandex.ru
\end{abstract}

(Received: 1 March 2019; accepted: 3 June 2019)

Межкультурное и межъязыковое взаимодействие славянского и ориентального мира насчитывает не одно тысячелетие. Не удивительно, что столь длительный контакт наложил отпечаток на языки народов Славии и Востока, обогатив их заимствованиями из области материальной и духовной культуры. Слово ориентальный (от лат. orientalis) имеет семантику 'восточный, свойственный странам Востока' (СИС 1988: 351); к ориентализмам обычно относят слова, принадлежащие к разным группам тюркских, а также иранских и арабо-семитских языков (БушЕЕвА 2006: 25). Заимствованию южнославянскими языками тематически разнообразных ориентализмов способствовали исторические события и языковые контакты. Итог пятивекового господства Османской империи на Балканском полуострове - заимствования из староосманского (старотурецкого) языка, ставшего как языком-источником, так и (часто) языком-посредником, через который в южнославянские языки-реципиенты вошли арабизмы и персизмы: «Результатом исламизации славянского населения Балкан стало проникновение в их язык значительного числа турцизмов и арабизмов (ведь на протяжении довольно долгого времени официальными служебными языками были турецкий, арабский, а языком литературы и поэзии - персидский)» (ХМЕлЕвский 2013: 228). Поэтому в Болгарии для обозначения этой лексики используется еще термин туреико-арабско-персидские слова (Вътов 1998). Надо также учитывать, что помимо арабоперсидских элементов староосманский язык насыщен заимствованиями и из других языков (например, греческого). По этой причине в разных словарях наблюдаются расхождения в квалификации языка-источника лексем.

Под термином туриизмы обычно подразумевается лексика из староосманского, а не современного турецкого языка. Степень проникновения турцизмов в языки народов Славии различна. Так, в Болгарии в период Осман-

\footnotetext{
* Работа выполнена при финансовой поддержке проекта «Полиэтническая образовательная среда современного вуза: проблемы многоязычия и межкультурной коммуникации» (базовая часть государственного задания Министерства образования и науки Российской Федерации в 2017 г.) (№ 27.9712.2017/БЧ).
} 
ского владычества «практически существовал билингвизм», поскольку турецкий был официальным языком (СтояновА 2007: 100). Это относится также к Боснии и Герцеговине, к мусульманской части южных славян, но с оговоркой: таковым он был только у образованных слоев населения, связанного со сферой религии, поэзии, права, административной системой и т. п. (остальные были неграмотными). Ориентальная лексика проникала в языки южных славян в основном через устный разговорный язык.

Различна и судьба заимствований: они либо остались в языке-реципиенте экзотизмами, либо полностью усвоились им. Причем в отдельных случаях эти слова настолько укоренились в заимствующем языке, что «в результате переосмысления и экстралингвистических факторов приобрели новый концептуальный смысл, став символами самобытной культуры отдельных славянских народов» (ХмЕлЕвский 2018а: 118). Показательна в этом плане судьба арабизма майдан у украинцев, русских и сербов (см. ХмЕлЕвский 2018b), а также ориентализмов шаровары, кобза, лелека 'аист' в Украине, каймак, чевапи, ракия и некоторых других на Балканах (см. ХмЕлЕвский 2018а).

Ввиду обширности ориентализмов как особого генетического пласта южнославянской лексики ограничимся заимствованиями, называющими человека по разным основаниям - интеллекту, полу, роду занятий. ${ }^{1}$

Турцизм будала 'глупец, дурак, ненормальный' - одно из настолько освоенных слов на территории бывшей Югославии, что оно не воспринимается современными носителями языка как заимствование. Лексема входит в состав серб. као будала на свијету [как дураков на свете] 'достаточно' (КАРАџић 1849: 132); хорв. k’o budala (OмAzIĆ 2002: 120); razbucat što ka budala novine [разорвать что-л. как дурак газету] (VRANić-ZuBčıć 2013: 114). B хорв. glup kao budala (RHSFR 1979: 317) тавтология способствует выражению высокой степени качества. В разговорных шутливых боснийских устойчивых сравнениях с противопоставленными планами содержания и выражения с семантикой 'очень подходить, соответствовать' мы видим и другое заимствование из турецкого языка - щамар 'пощечина, оплеуха': sjesti (pristati) $k($ a)o budali šamar [подходить как дураку пощечина]; odgovara kome kao budali šamar [соответствует (подходит) как дураку оплеуха]. В мусульманской части Боснии для негативной оценки умственных способностей и интеллекта человека употребляется также слово $d z ̌ a h i l$ 'безграмотный, необразованный человек, неуч' - от осм.-тур. cāhil < ap. ğāhil 'тот, кто не знает, не обучен, неуч; необразованный; глупый, невежда; глупец, дурак’ (Š́HOVIĆ-HAVERIĆ 2017: 152). Коннотация пейоративности сохраняется и в сравнении, компонентом которого оно является: živjeti kao džahil 'жить в неведении, невежестве'; при замене ориентализма славянизмами neznalica, neuk компаративный фразеологизм разрушается.

\footnotetext{
${ }^{1}$ О компаративизмах с компонентом, которые встречаются в составе славянских устойчивых сравнений, называющим человека по титулу, административным и военным должностям, званиям см. КУЗНЕЦОВА 2018.
} 
Арабизм mahnit (< осм.-тур. muannid или anūt, anūd < ap. mu'ānid 'своенравный, упрямый; упорный, настойчивый; делающий наперекор, непослушный' или 'anūd 'упрямый, делающий назло, наперекор') имеет значение 'придурковатый, слабоумный; сумасшедший, умалишенный; бешеный’ Серб. покори се махниту, као и свету [подчинись юродивому как народу] (КАРАџић 1836: 261); поклони се махниту, ка' и свету [поклонись юродивому как (всему остальному) люду] (КАРАџић 1849: 316) отражает отношение к блаженным, понимание юродства как формы святости. Черногор. помаже як маниmу молитва пјаного попа (РАдовй 1962: № 4410) имеет семантику 'абсолютно не поможет'. В хорватских диалектах слово является компонентом в чакавском устойчивом сравнении $k a(k a j)$ manit 'о деспотичном, бешеном, вспыльчивом человеке' (VRANIĆ-ZuBčIĆ 2013: 105, 127). В штокавском говоре Хорватии оно зафиксировано в двух компаративизмах. Один построен на противопоставлении планов содержания и выражения: volit koga ka mater (majka) manitu ćer [любит как мать (мама) безумную дочь] 'не любит кого-л.' и имеет равнозначный вариант volit koga ka mater (majka) ludu ćer (VRANIĆZuBČIĆ 2013: 126). Второй - ирон. dočepat se kaj manit kape [дорваться как ненормальный до шапки] 'ненормально, неадекватно вести себя, когда получаешь то, что очень сильно хотел' (VRANIĆ-ZuBČIĆ 2013: 126) - синонимичен балканским сравнениям с образным конкретизатором лысый, плешивый: болг. диал. докопвам се/докопам се като келяв ${ }^{2}$ о шапка [дорваться как паршивый до шапки] 'дорваться до чего-л. сильно желаемого и очень необходимого’ (КювлиеВА 1986: 129); серб. докопао се као ћелав капе (КАРАџИЋ 1849: 68); босн. dokopati se čega kao ćelav kape 'наконец-то дождаться осуществления чего-л., получить что-л. давно желаемое и ни за какую цену не хотеть отказаться от него' (Š́HOVIĆ-HAVERIĆ 2017: 140). На боснийском ареале лексема зафиксирована также в устойчивых сравнениях čuvati kao ćelav kape 'очень сильно беречь; прямо дрожать, трястись от боязни потерять что-л.'; mijenjati kao ćelav kape 'часто менять что-л.' (Š́̈Hović-HaVERIĆ 2017: 140). Компаративизм ćelav kao koljeno 'абсолютно лысый' (ŠEHOVIć-HAVERIć 2017: 140) имеет вариант с основанием сравнения - славянизмом go kao koljeno (ŠEHOVIĆ-HAVERIĆ 2017: 140) и тождества (полные и неполные) без ориентального компонента в других славянских языках. ${ }^{3}$

Фразеосемантическая группа «Знания» на боснийском мусульманском ареале представлена несколькими устойчивыми сравнениями с компонентомориентализмом. Семантику 'отлично знать что-л.' имеет компаративизм роznavati (znati) kao evlija, где evlija - 'святой, праведник, добрый человек'; при

2 От тур. и перс. kel 'короста, плешь' (ŠкALлÍ 1966: 187); < осм.-тур. kel, keçel < перс. kal, kaćal (ŠEHOVIĆ-HAVERIĆ 2017: 140). Болг. кел 'парша'; босн. ćela 'место на голове, где больше не растут волосы’; ‘голова без волос'; ‘болезнь в виде парши, коросты на голове'.

${ }^{3}$ Рус. лысый как колено; голова [лысая, голая] как колено (ОГольцЕВ 2001: 264); укр. лисий як коліно (Юрченко-Івченко 1993: 73); бел. лысы (голы) як калена; галава як калена (СБНП 2011: 183); польск. tysy jak kolano; głowa [tysa] jak kolano (ПРФС 1: 536); чеш. hlava [lysá] jako koleno (ZAORÁLEK 2000: 465); слвц. hlava ako koleno (KSSJ 2003: 256). 
заимствовании лексемы произошло сужение семантики (< осм.-тур. evliyā < араб. 'awliyā', мн. от ед. walī) - 'друг, помощник, приверженец (сторонник), последователь; любимец, фаворит; ученик; племянник, свояк; товарищ, союзник; сосед; зять; родственник; близкий человек; защитник, опекун; благодетель; покровитель; господин; хозяин; собственник; святой; пророк; верующий; раб; ислам. богоугодник, добрый человек' (ŠEHOVIĆ-HAVERIĆ 2017: 160). В poznavati/znati šta kao hafiz [ajete] [знать (что) как хафиз аят] 'знать что-л. очень хорошо' содержится два ориентализма. Первый - hafiz от осм.-тур. $h \bar{a}-$ $f i z<$ араб. hāfiz. C прямым значением этой лексемы 'мусульманин, выучивший Коран наизусть' (чем мотивирована внутренняя форма устойчивого сравнения naučiti šta kao hafiz) связаны переносные: босн. 'о человеке с хорошей памятью'; 'о человеке, хорошо знающем что-л.' (ŠEHOVIĆ-HAVERIĆ 2017: 166), серб. хафиз (хафис) - 'ученый, образованный человек'; 'знаток' (РСХКЈ 6: 717). В арабском языке слово имеет и другие значения: 'ангел(-хранитель)', 'наместник края, области'. Второй компонент, арабизм ajet факультативный; он имеет семантику 'коранический стих; отрывок, изречение, строка из Корана (обычно одно предложение)' (ŠEHOVIĆ-HAVERIć 2017: 111). Аятов в Коране более шести тысяч двухсот, чем и мотивирована возможность расширения состава компаративного фразеологизма для освежения экспрессии.

В составе устойчивого сравнения poznavati/znati kao hodža ćitab [знать как ходжа Китаб] также два компонента-ориентализма. Персизм hodža в Боснии значит: 1. а) 'ислам. тот, кто образован и профессионально уполномочен выступать предводителем верующих в различных религиозных обрядах; следит за религиозной жизнью в рамках джамаата; имам, эфенди'; б) 'разг. тот, кто образован в религиозном плане'; 2. 'мусульм. преподаватель мусульманского религиозного учения; преподаватель религии'; 3. 'этнологич. тот, кто составляет записки людям, чтобы защитить их от разных болезней, сглаза, заговоров и т. п.' (Š́nović-Haverić 2017: 173). Арабизм ćitab (kitab < осм.тур. kitāb, kitap < apaб. kitāb $b^{5}$ ) у боснийских мусульман - это 'книга (особенно религиозная)' (ŠEHOVIĆ-HAVERIĆ 2017: 141), т. е. и здесь мы видим сужение объема значения. На боснийском мусульманском ареале слово hodža встречается и в других устойчивых сравнениях. Разговорное пейоративное выражение oduljiti/razvući $k(a)$ o hodža teraviju 6 [растянуть (затянуть) как ходжа теравию] означает 'преувеличенно долго и медленно делать, выполнять что-л.;

${ }^{4}$ От осм.-тур. hoca, $h \bar{a} c e<$ перс. $x \bar{a} \breve{g} e$ - 'человек высокого положения; великий, известный человек, выделяющийся своими способностями; авторитетный человек, образец для подражания; тот, с кого берут пример; богач, богатый человек; торговец; истор. высокий государственный чиновник в бывшей Османской империи; министр; губернатор края'.

5 'Книга; священная книга, писание; письмо; документ, свидетельство; сочинение, произведение; акт, документ; регистр, книга регистрации; рукопись; закон, завет; юридический акт, распоряжение; договор, соглашение; судебное постановление; обязательство; распоряжение, приказ; судьба'.

${ }^{6}$ Terávija (< осм.-тур. terāvī, terāvīh < араб. мн. ч. tarāwīh от ед. ч. tarwīha) - 'ночной намаз во время рамазана; поклонение во время молитвы через два часа после захода солнца; теравих-намаз'. 
слишком затянуть (о времени)' ('̌́ паративизма kao da je hodži s tabuta pobjegao [как будто у ходжи из табута убежал] 'очень бледный, изнуренный' перекликается с образностью известного многим славянским народам фразеологизма как из гроба встал. Ирония mrziti kao hodža rahat-lokum [ненавидеть как ходжа рахат-лукум] 'очень любить’ обусловлена антонимией плана содержания и плана выражения. Лукум или рахат-лукум (< осм.-тур. lokum, rahat-lokum) - сладкие кусочки из сахара с добавлением крахмала и орехов, одно из самых популярных кондитерских изделий на Балканах - пришел из Турции (тур. rahat-lokum букв. 'прелестный, лакомый кусочек') (САВченко-ХМЕЛЕВСКиЙ 2017: 75). В хорв. диал. klanjat se ka turski odža ‘спать сидя’ (VRANIĆ-ZuBČIĆ 2013: 132) глагол имеет значения 'кланяться, нагибая голову' и 'молиться (о мусульманах)', причем образом сравнения является не анатолийский турок, а переселенец мусульманского вероисповедания из Боснии. Сравнение мотивировано тем, что, когда мусульмане читают намаз, они совершают обряд, напоминающий поклоны.

В сербских устойчивых сравнениях, зафиксированных Вуком Караджичем, лексема ходжа связывается с именем персонажа фольклора, анекдотов: промеће се, као хоца кроз поњ аву ' 'делать бесполезную работу'; пуха ка' хоиа на тикву ${ }^{10}$ [дуть как ходжа на тыкву] 'о негативном опыте, боязни повторить прошлые ошибки, действовать осторожно даже тогда, когда в этом нет необходимости'; као Насрадин хоиа (ради наопако) [как Ходжа Насреддин (делает наоборот)] 'делать шиворот-навыворот' (КАРАџић 1849: 132).

Гайдук ${ }^{11}$ - 'у южных славян, молдаван, валахов, венгров: борец за народную свободу против турецкого господства, повстанец-партизан’ (СИС 1988: 107). Но это исторически. На базе прямого значения 'человек, который воевал на Балканах против османов' у южных славян развилось дополнительное значение: болг. хайдук 'разбойник'; хайдутин 'разбойник, вор' (БРР 2002: 456); серб. ‘бунтовщик, мятежник вообще; разбойник' (РСХКЈ 6: 705), в воеводинских говорах хајдук - это 'ирон. вор, обманщик' ${ }^{\prime 2}$, что проясняет семантику болг. диал. влизам/влеза (вмъквам се/вмъкна се и под.) като хайдук (айдук) 'войти куда-л. очень тихо и незаметно' (КювлиЕВА 1986: 112). Значение серб. управио као хајдук кућом [управлять как гайдук домом] (КАРАџић

${ }^{7}$ В Боснии, Герцеговине, южной Сербии табуm - 'мусульманский открытый гроб, у которого нет крышки, и его накрывают сверху тканью’.

${ }^{8}$ Фонетический вариант слова hodža.

${ }^{9}$ При сравнении есть примечание, суть которого в следующем: жена укоряла ходжу Насреддина и требовала, чтобы он не сидел без дела, а чтобы хоть что-нибудь делал; ходжа же, сделав удивленный вид и якобы поняв все совсем по-другому, расстелил во дворе тонкий коврик и, разрезав его, начал прыгать через него туда-сюда.

10 Пояснение к сравнению: некий ходжа, обжегшись, когда ел вареную тыкву, после дул на тыкву и когда видел ее в поле на стебле. Синоним - русская пословица Обжегшись на молоке, дуют на воду.

${ }^{11}$ По А. Шкаличу, схема заимствования слова такова: < тур. haydud, haydut 'разбойник с большой дороги' < венг. haydúk 'воин' < араб. инфинитив 'свернуть с истинного пути', откуда произошло значение ‘взбунтоваться, перестать подчиняться властям’ (ŠKALJÍ́ 1966: 300).

${ }^{12}$ Информант - М. С. Хмелевский. 
1836: 335) не совсем ясно. Выборный предводитель отряда гайдуков - $(x) a$ рамбаша; слово сложное, состоит из двух слов-ориентализмов: $(x)$ арам 'то, что запрещено верой; то, что в основе незаконно, нечестно; грех; проклятие' и баш 'голова'; оно также имеет значение 'разбойник' (РСХКЈ 6: 712). Обе лексемы, связанные с гайдучеством, зафиксированы в хорв. диал. klit ko hajduk и klit ko harambaša 'много и грязно ругается' (MALNAR 2011: 166).

Сквернословие часто ассоциируется с людьми, выполняющими неквалифицированную работу, которая не требует особого мастерства. ${ }^{13}$ У южных славян это нанятый носильщик: хорв. psovati kao hamalin (MATEŠIĆ 1982: 180); босн. psovati kao hamal ${ }^{14}$ (ŠEHOVIĆ-HAVERIĆ 2017: 170); болг. nсувам (ругая, попьржвам, проклинам) като хамалин (КювлиеВА 1986: 188, НБФР 1: 518) (< осм.-тур. hamal, hammāl< араб. hammāl 'носильщик; торба'). Причем слово - экзотизм, это не просто носильщик, а человек, специально нанятый, чтобы носить вещи; он постоянно жил в доме у османского чиновника, который часто переезжал с места на место по службе и держал у себя под рукой частного носильщика (в славянской традиции такого не было). Представитель этой профессии стал образом сравнения также в серб. носио [је] вреће као последюи хамалин [носил мешки (из грубой ткани) как последний носильщик] (РСХКЈ 6: 710); в босн. raditi (tegliti) kao hamal 'о человеке, занятом тяжелым, напряженным физическим трудом’ (Š́EOVIĆ-HAVERIĆ 2017: 170) и болг. пия като хамалин 'о злоупотребляющем алкоголем человеке'. ${ }^{15}$ В Болгарии пристрастие к спиртному и склонность к ругани связывают с представителем и другой непривилегированной профессии - легковым извозчиком: пия като файтонджия (БРФС 1974: 597); ругая (проклинам, попьржвам, псувам) като файтонджия (НБФР 1: 518). В этих примерах мы видим заимствованный корень - грецизм файтон (< phaethōn 'фаэтон, легкий четырехколесный экипаж с откидным верхом') и словообразовательный элемент - агентивный суффикс -дж- турецкого происхождения (тур. -ci- <- $d \check{z}-)$, активно участвующий в образовании слов данной тематики на южнославянском ареале. Но в устойчивых сравнениях таких слов не так уж и много: болг. въртя се като калайджия ${ }^{16}$ [вертеться как лудильщик] 'постоянно, непрерывно вертеться'; излагам се/ изложа се като кифладжия '17 'подвергаться опасности'; диал. лежа като селски чорбаджия ${ }^{18}$ 'лежать спокойно, долго, никуда не спеша и ни

${ }^{13}$ О славянских и немецких сравнениях с названием профессии см. КузнЕцОВА 2012.

${ }^{14}$ Перен. пейор. 'человек, выполняющий физически тяжелую работу (наемник, амбал)'.

${ }^{15} \mathrm{https} / / / \mathrm{bg}$.glosbe.com/bg/bg/бъбрив

${ }^{16}$ От тур. kalay 'олово'.

17 Человек, который готовит и продает кифлу (< нем.) - 'вид выпечки, сдобы из тонкого теста, свитой в виде молодого месяца' (РСХКЈ 2: 716).

${ }^{18}$ От тур. çorbaci 'тот, кто варит и продает чорбу'; перен. 'господин, начальник'. В османскую эпоху - янычарский чин, командир одной «орты», а также представитель сельской верхушки - староста, зажиточный крестьян, привлекаемый властью к работе в судебных и административных органах, из их числа обычно назначали сборщиков налогов. В Болгарии XVIII-XIX вв. так называли представителей социальных слоев, связанных с османской администрацией. В XIX в. слово стало применяться чаще всего к торговцам, богатым христианам. 
о чем не беспокоясь'; устар. перча се като селски чорбаджия 'сильно важничать, чваниться’ (КювлиЕвА 1986: 116, 141, 155, 177); диал. въртя се като калайджийка 'о непостоянной и ветреной женщине' (ФРБЕ 1: 201); серб. ирон. hajati (mariti) kao vrana za skeledžiju 'не заботиться о ком-л., абсолютно не волноваться за кого-л.' (МАТЕŠÍ́ 1982: 756); боји га се, као врана скелеције $e^{19}$ 'совсем не боится, не обращает внимания'; као Бог и шешириија ${ }^{20}$ 'сильно различаться' (КАРАџић 1849: 21, 129).

Прилагательное, образованное от существительного кираджия, ${ }^{21}$ встречается в следующих болгарских устойчивых сравнениях: като кираджийски кон 'делать что-л. автоматически, не думая, по привычке'; тегля (работя, трудя се) като кираджийски кон 'очень много, покорно, безропотно (обычно о тяжелой работе)' (ФРБЕ 2: 488); да работиш като кираджийски кон и да те хранят като врабче 'о непосильном труде за ничтожное вознаграждение' (НБФР 1: 146); натоварен като кираджийски кон 22 'об очень тяжело нагруженном человеке'; от субстантива халваджия ${ }^{23}$ - в компаративизме оплескал съм се като халваджийска тесла 'очень сильно испачкаться, измазаться' (КювлиевА 1986: 174), где тесло - 'род топора с лезвием, расположенным перпендикулярно топорищу'; от слова фурнаджия ${ }^{24}$ - в обороте въртя се като фурнаджийска лопата 'легко менять свое мнение, быть непоследовательным в своих действиях, поступках’ (ФРБЕ 1: 202). Диал. въртя се като калайджийско дъно [часть брюк, штанов и т. д., которая охватывает зад] семантизируется по-разному: 'постоянно, не переставая вертеться' (КювлиЕВА 1986: 116) и ‘о непостоянной и ветреной женщине’ (ФРБЕ 1: 201).

Многие турцизмы стали историзмами, вышли из употребления в результате исчезновения тех реалий, которые они обозначали. Часть из них, связанная с системой администрирования в османскую эпоху, является компонентами устойчивых сравнений. Так, в болг. си обръсна главата като башибо$3 y \kappa^{25}$ 'о человеке с бритой головой' ${ }^{26}$ содержится устаревшая лексема башибузук, а в диал. ирон. прокопсал съм като мома у еничери ['девушка, девка'] 'никак не преуспел, не добился удачи' (КювлиЕВА 1986: 187) - турцизм янычар. ${ }^{27}$ Образ сборщика налогов лег в основу устойчивых сравнений болг. диал. треперя като цчиганин пред харачия 'сильно дрожит (от страха)' (КювлиЕВА

${ }^{19}$ Скелеција - 1. ‘плотогон, сплавщик (плотов)'; 2. ‘перевозчик, паромщик’. От тур. iskele < итал. skala < лат. skala (ŠKALJÍ́ 1966: 567).

20 'Тот, кто делает и продает головные уборы; шляпочник'.

${ }^{21}$ Во время османского господства на Балканах - специализированная группа от райя, перевозившая товары в своих повозках, телегах (собират. истор. райя [болг. рая, серб. раја $<$ тур. < араб.] 'христиане - подданные Турции, платившие дань').

${ }^{22} \mathrm{https}: / /$ translate.academic.ru/натоварвам/xx/xx/

23 'Тот, кто готовит и продает халву'.

24 'Пекарь, хлебопек' (от тур. furun < греч. foûrnos 'печь').

${ }^{25}$ Солдат нерегулярных частей турецкой армии: из тур. bašybozuk от baš 'голова' и $b u$ $z u k$, bozuk 'бешеный, испорченный' (ФАСМЕР 1: 138).

${ }^{26} \mathrm{https}: / / \mathrm{ru} . \mathrm{glosbe} . \mathrm{com} / \mathrm{ru} / \mathrm{bg} /$ бшибузук

27 'Привилегированный пехотинец в султанской Турции до 1826 г., выполнявший также полицейские и карательные функции’ (СИС 1988: 597). 
1986: 188); серб.-хорв. bježi od njega kao od haračlije 'всячески избегай кого-л.' (ŠKALJí 1966: 312). ${ }^{28}$ В болгарских диалектных компаративизмах встречается и другое наименование сборщика налогов арабо-турецкого происхождения: обтегнал се като новоселски кабзумалин 'лежать спокойно, блаженствуя, не испытывая беспокойства’ (КювлиЕвА 1986: 172); ходя като селски капзамалин 'держаться надменно, расхаживать с напыщенным, гордым видом'. ${ }^{29}$

Во многих языках слово мясник кроме прямого значения имеет и переносные - 'плохой, бездарный, невежественный хирург' и 'жестокий человек, беспощадный убийца, головорез'. Не исключено и арабо-турецкое заимствование в южнославянских языках, которое зафиксировано в устойчивых сравнениях: болг. гледам като касапин 'смотреть свирепо, кровожадно, страшно'; закървавил очи като касапин 'о налившихся кровью глазах (обычно от гнева, ярости)’ (КювлиЕвА 1986: 120, 135); серб. исећи као касапин (месар) месо 'разрубить, разрезать (на куски, на части)' (Ђинъић 2013: 311) - ср. также с хорв. Normalno je da te hirurg secka kao kasapin stoku! ${ }^{30}$

Некоторые устойчивые сравнения содержат в своем составе мусульманские константы. Например, босн. ponašati se kao gazija ${ }^{31}$ [вести себя как победитель, герой] 'вести себя воинственно, чересчур смело' (ŠEHOVIĆ-HAVERIć 2017: 165). Это относится также к сербскому выражению Храни коња, као брата, а јаши га, као душманина ${ }^{32}$ [Корми коня, как (родного) брата (близкого друга), но езди на нем, как на враге] (КАРАџић 1836: 343). Со сферой религии связан и боснийский компаративный фразеологизм smesti (zbuniti) se kao bînamāz među dvije džamije [смешаться, прийти в замешательство как бинамаз между двумя мечетями] 'совсем растеряться, смутиться, сконфузиться' (ŠEHOVIĆ-HAVERIĆ 2017: 124) и хорватская пословица Šta si stao ko' binamaz među dvije džamije (Š́KALJĆ 1966: 143), в составе которого содержится арабизм džamija 'мечеть' (< осм.-тур. саті̄ < ар. ğāmi') и персизм bînamāz - 'ислам. мусульманин, который не совершил намаз' (< осм.-тур. bīnamāz 'тот, кто не совершает намаз' < перс. префикс $b \bar{l}$ - и осм.-тур. namāz 'намаз, молитва').

Этнокультурную информацию передает болг. разгърдил се като пехли$в а н и \mu^{33}$ ['борец, практикующий вид народной борьбы; богатырь; синоним слова герой'] 'сильно распахнуть одежду или неприлично расстегнуть верх-

${ }^{28}$ От harač ‘подушная подать с ужчин-немусульман' (от тур. < араб.). Слово встречается в сербском сравнении као да је хараче (по Босни) купио [словно дань в Боснии собрал] 'такой толстый и красный' (КАРАџИЋ 1849: 130).

${ }^{29} \mathrm{http}: / /$ zdrasti.info/e-hadzhieva-a-asenova.html?page $=4$

${ }^{30} \mathrm{https} / / /$ kuthumimanu.wordpress.com/2017/01/08/primitivna-grubijanska-savremena-medici na-b-lipton-6-1/n

${ }^{31}$ Газий (от осм.-тур. $g \bar{a} z \bar{\imath}<$ араб. gāzin 'завоеватель, захватчик; нападающий; воин') воитель за веру (ср. с крымско-татар. гъазы 'борец за ислам в средние века'), почитаемый титул воеводы, победившего в битве во времена Османской империи, герой. В Боснии и Сербии слово имеет значения: экспр. 'юнак, герой; почетное звание воина-победителя'; перен. пейор. 'тот, кто действует насильно, насильник' (ŠEHOVIĆ-HAVERIĆ 2017: 165, PCXКJ 1: 460).

${ }^{32}$ От осм.-тур. düşman < перс. 'неприятель; заклятый, смертельный враг'.

${ }^{33}$ От тур. pehlivan 'артист, акробат; герой' < перс. pehlewān, pehluwān (ŠKALJIĆ 1966: 514). 
ние пуговицы или молнию на груди' (КювлиевА 1986: 191). Интересно, что сербский язык заимствовал лексему с исходной семантикой 'канатоходец; артист, демонстрирующий акробатическое мастерство на натянутом в воздухе канате, тросе, толстой веревке', что иллюстрируют пословица Два пеливана на једном конопу, ужету играти не могу [Два канатоходца ходить по одному канату не могут] и устойчивое сравнение ићи као пеливан на ужету, вычленяемое из текстов (РСХКЈ 4: 380), хотя турцизм пехливан 'пеливан' имеет также значения 'шут', 'герой, победитель', 'конь для быстрой верховой езды' (РСХКЈ 4: 380).

Лексема $\dot{c} a n g \bar{\imath}$ в персидском языке имеет семантику 'арфистка'. В сербский и боснийский языки слово пришло как ченгuја (čengija) 'певица в кабаке, цыганка-танцовщица'. Представить ее танец помогают строки из известного романа Иво Андрича «Мост на Дрине»: «почињао да игра... пуцкетајући прстима и вијући се у пасу као ченгија...» [он пускался в пляс... прищелкивая пальцами и извиваясь (в талии) словно уличная танцовщицацыганка...]. Сейчас прямое значение устарело; с ним связаны переносные: 1. 'пейор. злая, вспыльчивая, гневливая женщина'; 'неразборчивая женщина, женщина легкого поведения’; 2. ‘фамильяр. чертовка, вертихвостка, неуравновешенная, взбалмошная девушка'. Слово является компонентом сравнений: серб. горе јој очи као у ченгије [горят ее глаза как у ченгии] (говорят женщине, которая бесстыдно, вызывающе смотрит); ужегла очи [зажгла глаза] као ченгија (КАРАџИЋ 1849: 44, 329); босн. ос̌i kao u čengije 'о глазах, выражающих страсть, похоть' (Š́EHOVIĆ-HAVERIĆ 2017: 133).

Ориентальная лексика, относящаяся к женщинам, зафиксирована в боснийских компаративных оборотах živjeti kao hanuma 'жить комфортно, без забот и хлопот’ (ŠEHOVIĆ-HAVERIĆ 2017: 121, 170) и разг. zaboravljati $k(a) o$ mahaluša šamiju $u^{34}$ [забывать как женщина из махалы платок] 'быть забытым; забыть что-то очень важное'. В первом случае образом сравнения является ханума - 'госпожа', 'жена, супруга' (у мусульман) (< осм.-тур. hanım 'женщина, дама', 'жена, супруга'; 'хозяйка дома, госпожа, домашняя хозяйка'), во втором mahaluša - 'paзг., nейор. женщина, которая хочет быть детально осведомлена обо всем, что происходит вокруг, о том, что у кого случилось'; 'женщина, которая разносит слухи о других, сплетница'. Mahala (< ocм.-тур. mahalle < араб. mahalla 'постоялый двор'; 'квартал города') - район в боснийских мусульманских населенных пунктах, обычно захолустный, на отшибе; в представлении местного населения - это какая-то дыра, окраина, где люди с ограниченным сознанием, которым нечем заняться, кроме как ходить на рынок и сплетничать.

На территории бывшей Югославии употребляется слово була (< осм.тур. bula - 'старшая сестра; тетя по отцу или матери'). Оно трактуется как 'женщина-мусульманка', ‘незамужняя турчанка'. Мы приведем наиболее раз-

\footnotetext{
34 'Пестрый платок из тонкой ткани, которым женщины (обычно мусульманки) покрывают голову’ (от осм.-тур. şāme < перс. šăme).
} 
вернутую дефиницию: 1. 'ислам. женщина с профессиональной квалификацией, с образованием, с навыками какой-то профессиональной деятельности: а) по религиоведению; преподаватель ислама, муаллима, б) по исполнению мусульманских обрядовых действий'; 2. 'разг., пейор. женщина, одетая по исламским канонам - в длинной широкой одежде с платком на голове, который называется ma(h)rama'; 3. 'ycmap. женщина-мастерица, рукодельница (в виде обращения с уважением)' (ŠEHOVIĆ-HAVERIĆ 2017: 127). Слово встречается в ироничных хорв. vrijedi komu kao buli gaće 35 (МАTЕŠÍ́ 1982: 49); серб. вреди му као (ко) були гаће (РСХКЈ 1: 302) 'абсолютно не подходит; нет никакой пользы от чего-л.'; као (кано) були гаће [помагати] 'абсолютно не помогать' (ТрофимкинА 2005: 26). Семантику 'неготовый, неподготовленный; делать что-л. наугад, на авось, невпопад’ имеют серб. као була (грлом) у јагоде (РСХКЈ 1: 302) и хорв. kao bula u jagode (МАТЕŠIĆ 1982: 49) 'идти неподготовленным к чему-л.', ср. босн. ići kao bula (ŠEHOVIĆ-HAVERIć 2017: 127) и хорв. шток. ić ko bula u jagode (VRANIĆ-ZuBČIć 2013: 123). Манера одеваться подчеркивается в диалектных хорватских компаративизмах biti [odjeven] kao (ko) bula (Lukić-Blahević KREZIĆ 2012: 333); zamat'âua sę ję ko t'urska b'ula (MALnAR 2011: 158). Ср. также со следующими строками: «Зато, као була, Ката лице крије / И клони се људи к'о од живе ватре». ${ }^{37}$ В хорватских говорах также зафиксированы устойчивые сравнения izbirat ka bula jagode 'быть чересчур разборчивым' (штокав.) и sakire se kaj bula 'скрываться, не выходить из дома’ (чакав.) (VRANIĆ-ZuBČIĆ 2013: 123). Болг. диал. пуля се като була в мътеница 'глуповато вытаращить глаза', записанное в XIX в. П. Р. Славейковым (цит. по КювлиЕВА 1986: 188), содержит лексемы була (булла) - разг. 'замужняя турчанка' и мътеница - 'традиционный болгарский напиток из кислого молока с водой (наподобие айрана); получается в процессе приготовления в домашних условиях сливочного масла из полуферментированного молока, которое начало слегка створаживаться, свертываться'.

В очень редких случаях компаративизм с компонентом-турцизмом имеет равнозначный вариант со славянизмом: босн. živjeti kao beduin ${ }^{38}$ - živjeti kao pustinjak 'вести уединенный образ жизни' (ŠEHOVIĆ-HAVERIć 2017: 78); серб. бојати се [некога, нечега] као врана скелещије - бојати се [некога, нечега] као врана бродара; марити (хајати) [за некога, за нешто] као врана за скелецију - марити (хајати) [за некога, за нешто] као врана за бродара. ${ }^{39}$

Диалекты данных языков сохраняют значительно большее количество турцизмов, чем подвергшаяся политике пуризма литературная норма. Материал выявил перевес диалектных устойчивых сравнений рассматриваемой

35 'Подштанники, кальсоны; штаны (крестьянские)'.

36 'Клубника, земляника'.

${ }^{37} \mathrm{http}: / /$ media.bsmmc.rs/2017/02/Zorka-Stojanovic-OZILJCI-PREBOLJENIH-RANA-1.pdf

${ }^{38}$ Бедуин - араб, ведущий (полу)кочевой образ жизни (< осм.-тур. bedevī < ap. мн. badawiyyūn от ед. badaw̄ 'относящийся к пустыни'; ‘бедуинский'; ‘житель пустыни, бедуин').

${ }^{39} \mathrm{https}: / /$ slavovs.files.wordpress.com/2015/07/c491 orc491e-otac5a1evic487-frazeoloc5a1kirec48dnik.pdf 
тематики в южной Славии над образными универсалиями; обычно они идиоэтничны. Таково, например, болг. диал. надявам се като вдовица за ерген ['неженатый мужчина; парень; холостяк'] 'надеяться на что-то труднодостижимое, трудноосуществимое’ (КювлиевА 1986: 167).

Одна из причин ухода в пассив турцизмов на Балканах - процесс замены исконными словами, а в Болгарии и заимствованиями из русского языка (СтояновА 2007: 100). Если в большинстве южнославянских регионов компаративизмы с компонентом ориентального происхождения стали экзотизмами и историзмами, вышли в пассивный запас в связи с утратой образами сравнения своей актуальности, то в Боснии они встречаются в новейших изданиях (прежде не фиксировались словарями).

\section{Литература}

БРР 2002 = АНГЕЛУШЕВА М. Българско-руски речник. София: Л\&В ПРЕС, 2002.

БушеЕВА 2006 = БушеЕВА А. И. Еще раз об ориентализмах. В кн.: Материаль научной конференции ТГГПУ. Казань: Издательство Татарского государственного гуманитарно-педагогического университета, 2006. 23-27.

Вътов 1998 = Вътов В. Лексикология на българския език. Велико Търново, 1998.

Ђинъић 2013 = Ђинъић М. С. Туриизми у савременом српском книжевном језику (семантичко-деривациона анализа). Докторска дисертација. Београд, 2013.

КАРАџИЋ 1836 = КАРАџИЋ Вук Ст. Српске народне пословице и друге различне као оне у обичај узете ријечи. У народној штампарији на Цетињу, 1836.

КАРАџИЋ 1849 = КАРАџИЋ ВУк Ст. Српске народне пословице и друге различне као оне у обичај узете ријечи. У Бечу: У штампарији Јерменскога манастира, 1849.

КузнЕцОВА 2012 = КузнЕцОВА И. В. Славянские устойчивые сравнения с компонентом-названием профессии. В кн.: Die Phraseologie in Raum und Zeit. Фразеология во времени и пространстве. Greifswald: Ernst Moritz Arndt Universität, Санкт-Петербург: СПбГУ, 2012. 110-113.

КузНЕцОВА 2018 = КузНЕцОВА И. В. Ориентализмы-названия титулов в устойчивых сравнениях славян. В кн.: Русский язык и литература в тюркоязычном мире: современные концепции и технологии. Т. 1. Казань: Издательство Казанского университета, 2018. 236-240.

КЮВЛИЕВА 1986 = КЮВЛИЕВА-МИШАЙКОВА В. Устойчивите сравнения в българския език. София: Издателство на Българската академия на науките, 1986.

НБФР = НикОловА-ГълъБОВА Ж. Немско-български фразеологичен речник. Т. 1-2. Пловдив: Летера, 2001.

ОГОЛЬЦЕВ 2001 = ОГОЛЬЦЕВ В. М. Словарь устойчивых сравнений русского языка (синонимо-антонимический). Москва: «Русские словари», «Астрель», «АСТ», 2001.

РСХКЈ = Речник српскохрватскога књижевног језика. Т. 1-6. Нови Сад: Матица српска, Загреб: Матица хрватска, 1967-1976.

САВЧЕНКО-ХМЕЛЕВСКИЙ 2017 = САВченКО А. В., ХмЕЛЕВСКИЙ М. С. Образная символика с компонентом национальных блюд у украинцев, сербов и хорватов. Studia Slavica Hung. 62 (2017): 69-76.

СБНП 2011 = Слоўнік беларускіх народных параўнанняў. Мінск: «Беларуская навука», 2011. 
СИС 1988 = Словарь иностранных слов. Изд. 15-е, испр. Москва: «Русский язык», 1988.

СтояновА 2007 = СтояновА Н. И. Турцизмы во фразеологизмах болгарского языка. Вестник Дагестанского ГУ. Гуманитарные науки. Вып. 6. Махачкала: ИПЦ ДГУ, 2007. 100-105.

ТРОФИМКИНА 2005 = ТРОФИМКИНА О. И. Сербохорватско-русский фразеологический словарь. Москва: «Восток-Запад», 2005.

ФАСМЕР = ФАСМЕР Макс: Этимологический словарь русского языка. Т. 1-4. Москва: «Прогресс», 1986-1987.

ФРБЕ = НИЧЕВА К., СПАСОВА-МИХАЙЛОВА С., ЧОЛАКОВА Кр. Фразеологичен речник на българския език. Т. 1-2. София: Издателство на Българската академия на науките, 1974.

ХМЕЛЕВСКИй 2013 = ХмЕЛЕВСКий М. С. Особенности фразеологии города Сараева. В кн.: Национальное и интернациональное в славянской фразеологии. XV Международный съезд славистов. Минск: «Беларусь», Greifswald: Ernst Moritz Arndt Universität Greifswald, Institut für Slawistik, 2013. 227-231.

ХМЕЛЕВСКИЙ 2018a = ХМЕЛЕВСКИй М. С. Концептуальное переосмысление тюркизмов, ставших национальными символами славянских народов. В кн.: Межэтническое взаимодействие в поликультурном образовательном пространстве: проблемы языкового взаимодействия и межкультурной коммуникации. Чебоксары: Чувашский государственный педагогический университет, 2018. 118-124.

ХмЕЛЕВСКий 2018b = ХмЕЛЕВСкий М. С. Ориентализм «майдан» и его лексико-семантические трансформации в современном славянском мире. В кн.: «Ұль Дала» III-мі халықаральқ гуманитарлық выльымдар форумының материалдары (бірінші бөлім) / Материаль III гуманитарного форума «Великая степь». Т. 1-2. Астана: «Ғылым», 2018. 483-491.

ЮрчЕНКО-ІВчеНКО 1993 = ЮрченКО О. С., ІВчЕНКО А. О. СЛовник стійких народних порівнянь. Харків: «Основа», 1993.

KSSJ 2003 = Krátky slovník slovenského jazyka. Bratislava: Veda, 2003.

LukiĆ-Blažević Krezić 2012 = Lukić M., Blažević KreziĆ V. Frazemi u pripovijetkama Josipa Lovretića. In: BıLIĆ Anica (ured.): Šokačka rič 9. Vinkovci: Zajednica kulturno-umjetničkih djelatnosti Vukovarsko-srijemske županije, 2012. 295-338.

Malnar 2011 = Malnar M. Poredbeni frazemi u čabarskim govorima. Filologija. № 57. Zagreb, 2011. 155-173.

MATEŠIĆ 1982 = MATEŠIĆ J. Frazeološki rječnik hrvatskog ili srpskog jezika. Zagreb: Školska knjiga, 1982.

OMAZIĆ 2002 = OMAzIć M. O poredbenom frazemu u engleskom i hrvatskom jeziku. Jezikoslovlje. № 3. Osijek, 2002. 99-129.

RHSFR 1979 = MENAC M. Rusko-hrvatski ili srpski frazeološki rječnik 1-2. Zagreb: Školska knjiga, 1979.

ŠEHOVIĆ-HAVERIĆ 2017 = ŠEHOVIĆ A., HAVERIĆ Đ. Leksika orijentalnog porijekla u frazemama bosanskog jezika. El. knjiga. Sarajevo: Filozofski fakultet, 2017. http://www.ffeizdavastvo.ba/Books/Leksika_orijentalnog_porijekla_u_frazemama_bosanskog_jezi ka.pdf

ŠKALJIĆ 1966 = ŠKALJIĆ A. Turcizmi u srpskohrvatskom jeziku. Sarajevo: Svjetlost, 1966.

VRANIĆ-ZubČIĆ 2013 = VRANIĆ S., ZuBČIĆ S. Turcizmi u frazemima hrvatskih govora. Filologija. № 60. Zagreb, 2013. 103-145.

ZAORÁLEK 2000 = ZAORÁLeK J. Lidová rčení. Praha: Academia, 2000. 
IRINA VLADIMIROVNA KUZNETSOVA

Department of Pedagogy and Methodology,

I. Yakovlev Chuvash State Pedagogical University (Cheboksary)

\section{Orientalisms-Anthroponyms in Similes of the Southern Slavs}

The author discusses similes of southern Slavs (Bulgarians and peoples of the former $\mathrm{Yu}-$ goslavia, i.e. Bosnians, Serbs, Croats, and Montenegrins) with a semantically similar component such as an anthroponym of Oriental origin. The author deals with both outdated similes and those that are actively used nowadays.

Orientalisms usually include words belonging to different groups of Turkic as well as Iranian and Arab-Semitic languages. Historical events and language contacts contributed to the borrowing of thematically diverse Orientalisms by South Slavic languages. The result of the five-century domination of the Ottoman Empire in the Balkan Peninsula is borrowing from the Old Ottoman (Old Turkish) language, which became both the source language and (often) the intermediate language through which Arabisms and Persisms entered the South Slavic recipient languages. Therefore, in Bulgaria, the term Turkish-Arabic-Persian words is used to refer to this vocabulary. In addition to the Arab-Persian elements, the old Ottoman language is rich in borrowings from other languages (e.g. Greek). The term Turkish usually refers to the vocabulary of the old Ottoman rather than the modern Turkish language. Due to the vastness of anthroponyms of Oriental origin as a special genetic layer of South Slavic vocabulary, the author analyzes the expressions that denote a person in such aspects as intelligence, gender, and occupation.

Oriental vocabulary penetrated into the languages of Southern Slavs mainly through oral spoken language. The degree of penetration of Turkish words into the languages of the peoples of Southern Slavia is different. The outcome of borrowings also varies: they either remained in the recipient languages as exoticism, or have been completely assimilated in them. During semantic adaptation in the language that accepts Oriental vocabulary, there is sometimes an expansion or contraction of the meaning of a word. Many of the Turkish words that make up the comparison became historicisms and entered the passive vocabulary and in the modern language they are not used because of the disappearance of the realities they denote (for example, words associated with the system of administration in the Ottoman era). Another reason for transition into the passive vocabulary in the Balkans is the process of replacing the original words.

The paper defines the functional, semantic, and stylistic status of Eastern vocabulary in different social and cultural layers (standard languages and dialects) of South Slavic similes. Due to historical reasons, the greatest number of borrowings from the Turkish language as a part of similes is observed in Bosnia and Herzegovina as well as in Shtokavian dialects of Croatia. In addition to this, the author gives cultural, historical, and etymological comments to similes, analyzing the meaning of units and components that are parts of similes.

Keywords: Oriental loanwords, Turkish, anthroponym, phraseology, similes, South Slavic languages, standard language, dialects, cultural and national identity, active and passive vocabulary 